come to recognize how its great virtues are not inseparably bound up with the out-dated practices which frequently invite criticism. The Franks proposals on postgraduates, for example, will be welcomed with enthusiasm in most colleges. So will be the administrative reforms intended to make the University more cohesive. In one sense the Franks Commission has already attained one of its principal objectives, for the public discussions which accompanied the process of collecting evidence has awakened the University to the opportunitics of change. Even at All Souls, there will be a measure of delight.

\section{CLOSING THE MOHOLE}

$\mathrm{T}$ HE future of the American project to drill a hole through the mantle of the Earth now seems in doubt. A week ago the Committee on Science and Astronautics of the U.S. House of Representatives jibbed at approving the new estimate of 28 million dollars for the cost of completing the Mohole. It remains to be seen whether the corresponding Senate committee will take the same view, but the prospects are not encouraging. For even if the Senate should consider that present costs are justifiable, the difforence between the House and the Senate would somehow have to be reconciled before work could go ahead. Nobody will be surprised that those most closely associated with the Mohole project have been cast down by this latest twist in the long and tortuous history of this project.

Two separate questions arise. The wisdom of the House Committee's decision is, for example, open to question, chiefly because the Mohole project is now so far advanced. A technique for drilling deep holes in the ocean floor has been developed, and orders for the drilling barges have been placed. By cancelling now, the U.S. Congress will save only a proportion of the total cost of the Mohole. It is capricious, to say the least of it, for the politicians to pull hard on the purse-strings at this late stage. It would have been much more to the point if they had taken a hard sceptical look at the project four years ago, for there was then good reason for believing that the drilling programme was being pushed ahead too quickly, and with too little preliminary study. A more deliberate programme might have been easier to contain within the bounds of a public budget, and might have been more rewarding as well. But Congress cannot put the clock back to the beginning by a crude cancellation.

The second issue is even more alarming. Hitherto, Congress has not exercised to any important extent its constitutional right to arbitrate on the fine details of scientific programmes financed by public money. It is true that plans for building-and siting-big particle accelerators have usually been examined in detail by Congressional committees, and the National Institutes of Health have occasionally been showered with more money than they could usefully spend, but the great public agencies have usually been allowed to manage their own affairs within the framework of a budget agreed by Congress. Though the details of the programmes of the National Science Foundation have been examined by Congress in the process of accounting for the spending of public money, Congress has usually trusted the judgment of its scientific public servants on the disposition of these funds. On the face of it, the Mohole decision looks like a departure from this practice. It could be a dangerous precedent.

\section{HELPING WISELY}

International Aid

By I. M. D. Little and J. M. Clifford. Pp. 360. (London: George Allen and Unwin, Ltd., 1965.) Cloth 45s. net; Paper 25s. net.

$I_{a}^{N}$ TTERNATIONAL aid follows no general pattern; it is a tangled skein of threads beginning with the motives and objectives of the donor countries, often entangled with international organizations, and ending with a group of largely unco-ordinated projects in each of the recipient countries. In International Aid, Mr. Little and Mrs. Clifford have performed a valuable service in setting out and analysing the efforts of the more developed countries to help those less fortunate. They have had a difficult task, but have carried it out with considerable success. At times it may seem that they have tried too hard to equate quite different forms of aid, but the exercise has value in that it brings out very clearly the complexity of the problem.

In the early chapters, dealing with the history and quantity of aid, the authors describe its many forms; thus it may be a gift of money with or without any strings, or the supply of materials, equipment or services, or again it may be a loan at any interest rate from nil to the full commercial level and with time of repayment differing equally widely. Further, aid may be given on a bilateral basis or through one of the international agencies or organizations, to which many nations contribute, sometimes freely, at others with restrictions in the form of blocked currencies. The tables given in the book are valuable in that they bring together the available facts, but they should only be read in the light of the qualifications well set out in the text.

One point is clearly brought out, namely that British aid has been far from generous compared with that of some other countries. Moreover, it has not followed any set policy or shown the degree of understanding of the problems involved which might have been expected of the probest ex-colonial power. The limited total of aid has arisen from Britain's own financial difficulties, but the funds available might have been used more effectively if the administration at home and in the recipient countries had been better. Both in the Government departments in Britain and on the staffs of the High Commissions and the Embassies there have been few professional advisers either in the economic or the technical aspects of the work. The few were grossly overloaded so that they were compelled to dash from place to place, with no opportunities to make the intensive studies required for the best allocation of aid. The staffs of the High Commissions and Embassies were more concerned with political questions, as befitted their training, so that the immediate advantage of agreeing quickly to a local demand has been allowed to outweigh the long-term gain which would have resulted from a careful detailed study of the needs of a country. The politician and diplomat have had an unnecessary fear of being branded as 'neo-colonialist'. They have not appreciated that a newly independent country, while violently resenting any political interference, would while violently resenting any economic and technical help provided this did not involve long-term contracts of employment and left the final decision to the country concerned, even though the technical advice might point to only one conclusion. This willingness to accept technical help is well illustrated in the recently published report of the Agricultural Research Council of Central Africa, where, in spite of all political differences, Rhodesia, Zambia and Malawi join with the United Kingdom and the United States in financing the work of an international staff.

One of the greatest needs of the less developed countries is for technical assistance. The staffing of a new and highly technical project is often completely beyond the means of a developing country. Help is required to get the project started and in the training of the men who will ultimately 